\title{
TITLE:
}

\section{CRITICAL INCIDENT REPORTING ON AN ACUTE PAIN SERVICE}

\section{AUTHORS:}

James E Paul MSc MD FRCPC*, Richard F McLean MD FRCPC*, Norm Buckley MD FRCPC* AFFILIATIONS:

*Department of Anesthesia, Hamilton Health Sciences, McMaster University, Hamilton, Ontario

\section{INTRODUCTION:}

The purpose of this project is to improve communication of critical incidents on the acute pain service (APS) so that the key players involved are consistently made aware of these events and have the opportunity to initiate quality assurance interventions when necessary.

\section{METHODS:}

After local REB approval, a computerized clinical database (APS Manager) was designed to capture relevant outcomes from APS patients including the details regarding critical incidents. The database was installed in three acute care hospitals in Hamilton in February 2002 and the systematic review and distribution of incident reports was started in September 2003. APS nurses identify critical incidents prospectively from data obtained from patient visits and a daily review of the patient's chart. Once identified, the APS nurses investigate and fill out a detailed incident report in the database that captures the details of the event, the clinical outcome and the actions taken. These reports are then flagged for review at a regular APS Steering Committee meeting and they are distributed to the Chief of Anesthesia, the Director of the APS, the Director of Perioperative Services, and Nurse Manger and Nurse Educator on the ward where the incident occurred. At the time of the APS Steering Committee meeting the most likely root cause of the incident is proposed and if the cause is related to system factors these are addressed with education and/or policy change interventions.

\section{RESULTS:}

Since this APS quality assurance improvement program was implemented there has been over 12000 patient enrollments, 20000 visits and 309 notable events recorded in Hamilton. As a direct result of this program, a number of interventions have been made to improve patient safety and the quality of analgesia provided.

Table 1. APS Quality Assurance Interventions

\begin{tabular}{|l|l|l|l|}
\hline \multicolumn{1}{|c|}{ Intervention } & \multicolumn{1}{c|}{ Type } & \multicolumn{1}{c|}{ Trigger } & \multicolumn{1}{c|}{ Rationale } \\
\hline $\begin{array}{l}\text { 1. Epidural and PCA pump programming } \\
\text { checked by second qualified RN prior to } \\
\text { initiating therapy }\end{array}$ & Policy Change & $\begin{array}{l}\text { Incidents of pain pump } \\
\text { programming errors }\end{array}$ & $\begin{array}{l}\text { Reduce/eliminate } \\
\text { programming errors }\end{array}$ \\
\hline $\begin{array}{l}\text { 2. Physicians encouraged to set 4-hour } \\
\text { limits in their PCA orders }\end{array}$ & Education & $\begin{array}{l}\text { Incidents of respiratory } \\
\text { depression with PCA patients }\end{array}$ & Reduce narcotic overdose \\
\hline $\begin{array}{l}\text { 3. APS nurses assigned to visit all epidural } \\
\text { patients the day after epidural removal }\end{array}$ & Policy Change & $\begin{array}{l}\text { Incidents of severe pain in } \\
\text { the transition from epidural to } \\
\text { oral analgesia }\end{array}$ & $\begin{array}{l}\text { Improve the quality of } \\
\text { analgesia after epidural } \\
\text { removal }\end{array}$ \\
\hline
\end{tabular}

\section{DISCUSSION:}

To address staffing, education and system issues related to critical incidents on an APS, it is necessary to systematically identify these events and communicate them to all of the key players involved in patient care. To move forward, it would be desirable for facilities to collaborate and research the policy options in order to make evidence based changes in the future. 